\title{
Hume on the Pre-Social State
}

Jeffrey $H$. Barker

Purdue University

There is a fundamental problem with Hume's account of the origin of society as given in the Treatise. ${ }^{1}$ In addition to problems concerning various aspects of law and property, Hume is inconsistent in his account of the origin of society and the reasons for its continued existence. Though the problem of the pre-social state seems unimportant at first, it will come to be seen as of great importance in Hume's descriptive project.

Hume takes great pains in the Treatise to stress that the state of nature as envisioned by either Hobbes or Rousseau could not have ever existed, that its existence is in fact a "mere," "idle," and "philosophical" flction--or does he?

But if it be found, that nothing can be more simple and obvious than that rule; that every parent, in order to preserve peace among his children, must establigh it; and that these first rudiments of justice must every day be improv'd, as the society enlarges: If all this appear evident, as it certainly must, we may conclude, that 'tis utterly impossible for men to remain any considerable time in that savage condition, which precedes society. . ..$^{2}$

From this it seems that Hume claims that what I will call the pre-social state could have existed for only a short while. Consider, however, the comments immediately following the last quotation:

- . but that his very first state and situation may justly be esteem'd social. This, however, hinders not, but that philosophers may, if they please, extend their reasoning to the suppos'd state of nature; provided they allow it to be a mere philosophical fiction, which never had, and never cou'd have any reality... . This state of nature, therefore, is to be regarded as a mere fiction, not unlike that of the golden age.'

From these latter quotations it would seem that Hume is denying even the possibility of a pre-social state. 
This is not, given Hume's account of society, as strange as it initially seems. It seems an obvious fact that, if primitive society is created by the coming together of male and female for breeding, very few, if any, human beings have ever been divorced from this society altogether, as they either participated in it or were a result of it (see $n$. 7 below). But this is not what Hume means. He means to say that the more advanced society--where parents institute rules and people band together--is the condition in which man finds himself, and the state previous to this, or at least previous to a slightly more primitive society, is impossible--a fiction.

This claim initially provides no problems for Hume's theory. Where it does provide problems is when Hume attempts to show why acts contrary to private in- terest are nonetheless performed. They are performed because, says Hume,

- . every individual person must find himself a gainer, on ballancing the account; since, without justice, society must immediately dissolve, and every one must fall into that savage and solitary condition, which is infinitely worse than the worst situation that can possibly be suppos'd in society."

Elsewhere in the Treatise ${ }^{5}$ Hume argues the same point: men have this common interest in preserving the stability of property and thus that of society, this interest being motivated by a fear of falling into the state of nature. Yet this state is a mere (idle, philosophical) fiction. In the Inquiry. Hume again terms the presocial state (and the golden age) a philosophical fiction, clting its use by Plato, Cicero, and Hobbes." He softens, however, his statements in the Treatise concerning the possibility of such a state, stating the problem as "whether such a condition of human nature could ever exist or, if it did... ." and ". . . this must be admitted, that, if such a state of mutual war and violence ever was real . . . "r But notice again, from the Inquiry, "[H]uman nature cannot, by any means, subsist without the association of individuals . . . .".

The problem that this inconsistency raises for Hume is a variant of the traditional problem of motivating just conduct, often discussed in the literature on Hume. The particular problem here is this: if the pre-social state of nature (taken especially in Hobbes' sense) $i_{\mathrm{s}}$ an idle, mere fiction, that did not and most importantly could not ever exist, then the individuals within a society cannot be motivated to just action by a fear of falling back into such a state. If, on the other hand, such a state is possible, or did exist, 
then Hume's account of human nature is weakened. This is so because of the mixed nature of man:

Human nature being compos'd of two principal parts, which are reguisite in all its actions, the affections and understanding; 'tis certain that the blind actions of the former, without the direction of the latter li.e., the condition of man in a Hobbesian state of naturel, incapacitate men for society...."

It should be noted here that this passage immediately follows as an explanation of why the pre-social state of nature could never have existed. This apparently results in the dilemma that either Hume's account of human nature is wrong--or human nature has changed--or Hume's account of the motivation to individual just action is empty.

There are several possible routes out of this dilemma. Hume could maintain that it is the fear of the pre-social state that motivates individual just actions despite the fact that it is an unfounded fear-that is, that it is an idle but efficient fiction. Though this is possible, it puts the stability of society on shaky ground and, more importantly, it would force Hume to admit that the advantage pursued by man in avoidance of falling into the pre-social state is artificial, that it is the result of a fiction rather than the general sense of common interest.

Another possible solution to the problen would be for Hume to claim that what is impossible is the Hobbesian war of all against all; what is feared by man is the primitive society of male, female and offspring without the regulation of property. This would solve the problem, but it is contrary to what Hume in fact says, as has been seen above.

Frankly, it is very difficult to reconcile Hume's statements on this problem. This becomes evident when examining some of the commentaries on Hume's account of justice. J. Kemp, for example, glosses over the use of the "idle fiction" as a motivation by asserting that

[Hume] argues that it is quite impossible for men to have existed for any length of time in such a condition [i.e.. in a pre-social state]; the basic rule of justice is a very simple one and it is unthinkable that men should put up with the unstable conditions of an existence in which rules of property and justice are unheard of . .

Indeed, it is unthinkable, and for Hume in the Treatise it is impossible. Kemp goes on to quite correctly assert that Hume nonetheless allows the use of the concept as a philosophical fiction, in an analogical 
argument linking the moral and natural sciences. This argument deserves examination.

Hume, after the passage concerning the two principal parts of human nature, goes on to claim in defense of the fiction:

And it may be allow'd us to consider separately the effects [of the affections and understandingl, that result from the separate operations of these two component parts of the mind. The same liberty may be permitted to moral, which is allow'd to natural philosophers; and 'tis very usual with the latter to consider any motion as compounded and consisting of two parts separate from each other, tho' at the same time they acknowledge it to be in itself uncompounded and inseparable. 11

This argument, though subtle and plausible, will not work if the philosophical fiction is used as a motivation-as Hume wishes to use it. Though the movement of, say, a horse from point $A$ to point $B$ is compounded and may be considered in its parts, the philosophical fiction of the pre-social state would require for its possibility a change in human nature (or its destruction), and thus the parts of human nature considered separately can never serve to motivate just acts, unless Hume admits the possibility of a change in human nature. This seems unlikely. So Hume can consider the pre-social state where man's nature is onedimensional, but this can never serve to inspire men to justice.

Terence Penelhum differs from Kemp in his interpretation of Hume on this pre-social state:

Hume rejects the claim that there has ever been a historical (sic) period during which men lived in $a_{.22}$ state of nature as envisaged by Hobbes...

Initially recognizing the problem of reconciling the use of the philosophical fiction as Hume wants to use it. Penelhum finds the solution fairly simple:

[The ideas of the state of nature and the golden age] merely show us why we need the conventions that we have when human nature is mixed in the way it 18.23

This is surely true and consonant with Hume's descriptive project. What Penelhum does not note is that Hume makes more use of the fiction than this. While the myths of the pre-social state show us why our conventions are the way they are, they can never influence us in the original formation and continuation of civil 
government, as it is impossible that we should ever return to this mythological pre-social state, due to the nature of human beings. And, of course, if the continuation of society and the rules of justice cannot be thus motivated, the natural question is: why should we be just as individuals?

D. G. C. MacNabb provides a clear illustration of the confusion on this point. At one point he states that ". . . Hume infers that men can never have existed anywhere for any considerable time in 'that savage state which precedes society' . . . ." and then also states that "[T]he lone savage, existing in Hobbes" state of war against all, is an abstraction who could scarce have been born or survived to maturity. . - "I* MacNabb finds this apparent inconsistency and Hume's use of the fiction relatively unproblematic.

Whatever the outcome of this problem, it is a variant of and points to another aspect of Hume's account of justice that deserves attention. It is evident that some just acts will be contrary to the private interests of the agent while not contrary to the general, public interest, and some just acts will be contrary to the public interest and beneficial to the private. Hume is required to show why individuals tend to promote the public interest over the private in cases where they clash, and why just acts apparently contrary to public interest are not in fact so opposed. One effort, just discussed, was to ascribe to men a fear of the collapse of society into a state of nature. The other, related, but more plausible way is to assert that, on the whole, individual interests are better furthered by adherence to the rules of justice, even when these rules seem contrary to the individual, private interest. On the other hand, single acts following from the rules of justice that appear contrary to public interest and beneficial to individual interest are seen as, on the whole, more conductive to the interests of society, especially to that key interest for Hume--stability. With this account Hume cements the relation between justice and interest in a curious synthesis of individual and public interest. After examining Hume's examples in detail, some criticisms will be offered of Hume's explanation.

\section{Hume states:}

A single act of justice is frequently contrary to public interest; and were it to stand alone, without being follow'd by other acts may, in itself, be very prejudicial to society. When a man of merit. . restores a great fortune to a miser, or a seditious bigot, he has acted justly and laudably, but the public is a real sufferer.

and 
Nor is every single act of justice, consider'd apart, more conductive to private interest, than to public; and 'tis easily conceiv'd how such a man may impoverish himself by a signal instance of integrity, and have reason to wish, that with regard to that single act, the laws of justice were for a moment suspended in the universe. 18

This being a very great problem for any system of justice based on interest, Hume offers the following solution:

But however single acts of justice may be contrary, either to public or private interest, 'tis certain, that the whole plan or scheme is highly conducive, or indeed absolutely requisite, both to the support, and the well-being of every individual. 'Tis impossible to separate the good from the ill. Property must be stable, and must be fix'd by general rules. ${ }^{26}$

One of the most interesting and insightful critiques of Hume's position here is that put forward by Barry Stroud. 17 Stroud asks us to consider a man, call him John, who is deciding whether to join a society based on the rules of justice. John may recognize the necessity of the existence of these rules in order to preserve stability, in property and thus in society. John is human, however, and thus partial to his own interests and to those of his friends and relatives. Moreover, John is fairly intelligent. He recognizes that society will not collapse should he act to serve his interests and those of his friends and relatives all of the time; justly, when justice coincides with his interests, unjustly when they diverge. Even when John admits that the rules of justice are to be universally binding in order to preserve society, still on Hume' $s$ account of human nature he may legitimately ask why he should act against his own interests when society is not directly threatened, as it rarely if ever is. He could still support the enforcement of the laws of justice as far as others are concerned, while acting solely in his own interests. This requires only the sacrifice of ethical consistency, but Hume's account does not make this sort of consistency necessary. ${ }^{1:}$

Stroud's example is admittedly improbable in its extreme character, but in fact history is dotted with such characters. The most notable example appears to be the Marquis de Sade, who while championing the order of justice for others, almost unreservedly followed his own interests. For a part of his life, when he was relatively immune from punishment, it was in his own interest to be quite unjust. Eventually, of course, Sade did suffer, and this may be a point in Hume's 
favor, though I think not. For as stroud mentions, 19 one could amend the example so that John is intelligent enough to take all pains in order to convince the rest of society that he does act justly, while secretly following his own interests. If he can do this with reasonable security, then the rules of justice on Hume's account hold little appeal for him, and thus Hume's descriptive account may fail.

Hume has two possible answers to stroud's criticism. The first, that men consider and fear the possibility of a fall into barbarism in weighing their courses of action, has been seen to be rife with difficulties. The second answer is that individuals are rewarded for action justly in the long run, that is," . . every individual must find himself a gainer, on ballancing the account . . . "20 The just act contrary to private interest thus only seems contrary to private interest, as ultimately those interests will be furthered. Likewise, just acts contrary to public interest only seem to be so, and in the end public interest is furthered. Hume here effects his curious synthesis of public and private interest. Unfortunately. this only seems to solve his problem. As stroud says,

- . this is really no better than the view already found to be inadequate $[i . e .$, the view that John embraces the rules of justice due to a recognition of interest]. What compensates for the evil resulting from individual acts of justice is presumably the greater security in preserving our goods which society provides. To reject justice, Hume argues, is to reject all the advantages of society. But the only way this could help explain an individual person's approval of, or motivation for, being just on a particular occasion is if, as Hume puts it, 'even every individual person must find himself a gainer, on ballancing the account'. And what reason is there to suppose that it is so? ${ }^{21}$

Put quite bluntly, there is no reason to suppose that individuals will, in the long run, be compensated for forsaking their interests for the interests of justice and the public good. Even if some sort of equalization does occur, Hume still has not accounted for just action, as in our example John may choose to perform a particular unjust action of the well-justified belief that the rest of society, ignorant of his action, will not follow suit and thus justice and society will be preserved.

Another of stroud's examples provides a striking rejoinder to Hume. If each person in fact approves of the rules of justice because he or she recognizes the eventual furthering of their private interests by doing 
so, then each criminal, should he think hard enough, would approve of his prison sentence as in the long run furthering his interests in some way; for example, by facilitating his integration into society at a later date after his rehabilitation. This is at least plausible. What private interest can possibly be furthered in the long run, when the criminal is sentenced to death?22

In either of the two routes Hume takes to explain the nature of individual just acts problems are encountered. This is not because Hume fails to provide normative, prescriptive guidelines; this is not his task nor does he claim it to be. Rather, Hume's account is weak because he fails to adequately describe how it is that justice works in society.

\section{NOTES}

'All references to A Treatise of Human Nature (hereafter 'Treatise') refer to the L. A. Selby-Bigge edition, revised with notes by $\mathrm{P}$. H. Nidditch (Oxford: Clarendon Press, 1978).

Ibid., p. 493

Ibid.

Ibid., p. 497.

Ibid., pp. 498, 505, 534 .

An Inguiry Concerning the Principles of Morals (1751). ed. by c. W. Hendel (hereafter , Inquiry') (Indianapolis: Bobbs-Merrill, 1957), pp. 20f. and n. 2 .

'Ibid., p. 21. Hume also admits heré that at least the society of the family is necessary.

Ibid. . p. 35 .

'Treatise, p. 493.

$10 \mathrm{~J}$. Kemp, Ethical Naturalism (London: st. Martin's Press, 1970), p. 41.

2'Treatise, p. 493.

'Terence Penelhum, Hume (New York: St. Martin's Press, 1975), p. 156. 


\section{3 ibid.}

"D. G. C. MacNabb, David Hume (London: Hutchinson's University Library, 1951), p. 179.

isreatise, p. 497.

\section{Ibid.}

1'Barry Stroud, Hume (Boston: Routledge and Kegan Paul, 1977), esp. pp. 205-18.

"Ibid. I have embellished stroud's example a bit. 19 Ibid., pp. $206 f$.

20 Treatise, p. 497.

2 stroud, p. 208 .

22 Ibid.. p. 210. Of course, in this example, it is always open to Hume to reject capital punishment. though it would not change the point. 